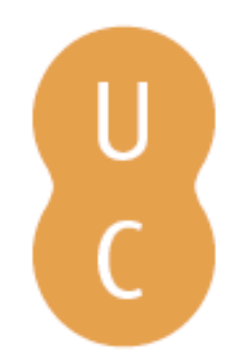

\title{
pommalina
}

\section{Consolidated financial statements}

Autor(es): $\quad$ Haustein, Ellen; Lorson, Peter C.

Publicado por: Imprensa da Universidade de Coimbra

URL persistente:

URI:http://hdl.handle.net/10316.2/47457

DOI:

DOI:https://doi.org/10.14195/978-989-26-1861-6_12

Accessed : $\quad$ 26-Apr-2023 15:10:55

A navegação consulta e descarregamento dos títulos inseridos nas Bibliotecas Digitais UC Digitalis, UC Pombalina e UC Impactum, pressupõem a aceitação plena e sem reservas dos Termos e Condições de Uso destas Bibliotecas Digitais, disponíveis em https://digitalis.uc.pt/pt-pt/termos.

Conforme exposto nos referidos Termos e Condições de Uso, o descarregamento de títulos de acesso restrito requer uma licença válida de autorização devendo o utilizador aceder ao(s) documento(s) a partir de um endereço de IP da instituição detentora da supramencionada licença.

Ao utilizador é apenas permitido o descarregamento para uso pessoal, pelo que o emprego do(s) título(s) descarregado(s) para outro fim, designadamente comercial, carece de autorização do respetivo autor ou editor da obra.

Na medida em que todas as obras da UC Digitalis se encontram protegidas pelo Código do Direito de Autor e Direitos Conexos e demais legislação aplicável, toda a cópia, parcial ou total, deste documento, nos casos em que é legalmente admitida, deverá conter ou fazer-se acompanhar por este aviso. 

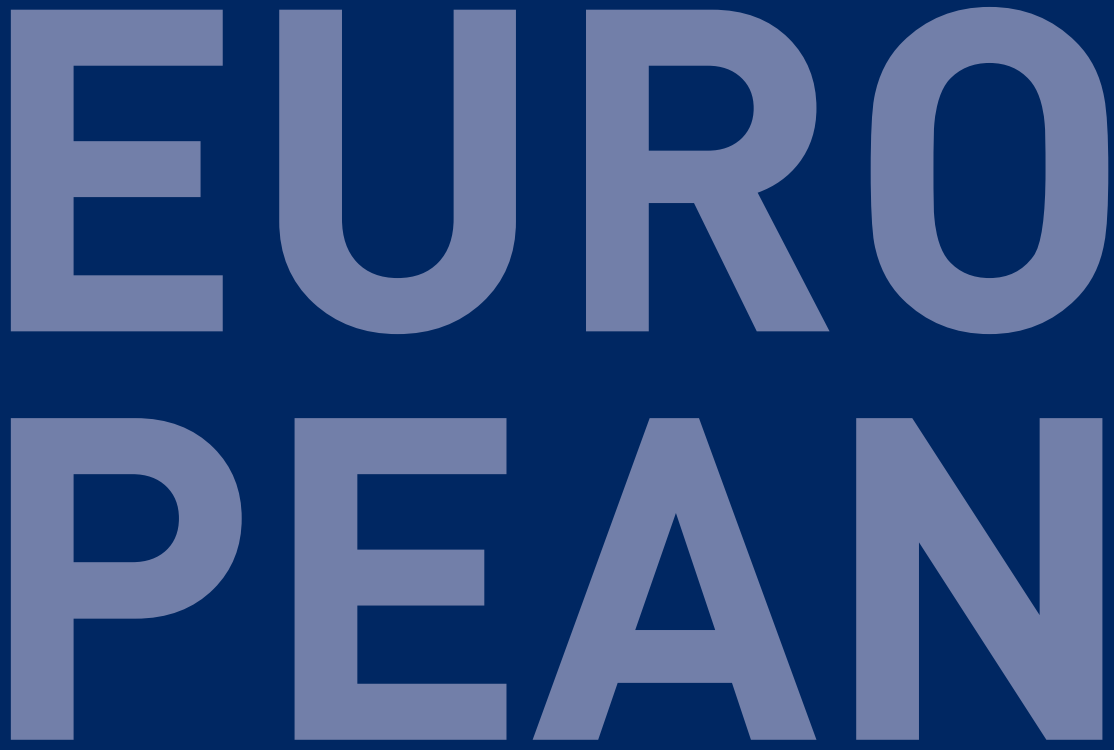

\section{PUBLIC SECTOR ACCOUNTING}

PETER C. LORSON SUSANA JORGE ELLEN HAUSTEIN

(EDS.) 


\title{
CHA P T E R 12
}

\section{CONSOLIDATED FINANCIAL STATEMENTS}

\author{
Ellen Haustein, Peter C. Lorson \\ both University of Rostock, Germany \\ ellen.haustein@uni-rostock.de \\ https://orcid.org/0000-0002-1218-1043 \\ peter.lorson@uni-rostock.de \\ bttps://orcid.org/0000-0002-2699-5451
}

\section{SUMMARY}

This chapter introduces consolidated financial reporting in general and highlights public sector specifics. The aim is to provide insights for the reasons for consolidation, the peculiarities in the public sector and underlying theories of consolidation. The chapter shows organisational challenges for preparing consolidated financial statements and explains the differences between consolidated financial statements and whole of government accounts. The different types of influences and methods for consolidation are explained. A short overview about consolidated financial reporting of this book's partner countries is presented.

KEYWORDS

Consolidation, consolidated financial reporting, whole of government accounting 


\section{Introduction: A group as an accounting phenomenon}

During the last chapters, financial statements (FS) of single sector public entities have been in the focus. However, often there are also public sector entities that have controlling relationships between each other. For example, a public sector entity does not only provide public services through its departments, i.e. the central administration, but also with the help of separate, legally independent operations such as public utility companies, municipal housing companies or wastewater associations. Together with the recent reforms in the public sector, an increase in collaboration between public sector entities and public corporations, and in public-private partnerships took place, which might require an "accounting tool that could provide financial information on the group as a whole"1.

In general, an economic entity (also called group) is formed of at least two legally independent entities: a (parent) controlling entity and (at least) one controlled entity (called subsidiary or special purpose entity in the private sector). This chapter deals with consolidated financial statements (CFS), i.e. financial information presented about the activities of a group of entities as if it were a single entity. ${ }^{2}$ Thereby, this chapter focusses on vertical subordinate groups, but not on horizontal peer groups. CFS do not simply sum up the SFS of the separate entities belonging to the economic entity, but aggregate the transactions of the controlling entity and its controlled entities by using consolidation techniques. The first CFS were already prepared by private sector entities around the turn of the $20^{\text {th }}$ century by U.S. accountants. ${ }^{3}$ For multinational private sector entities, CFS have become the norm, but in the public sector, reforms primarily in Anglo-Saxon countries have driven the adoption of 'consolidated accounts' or even 'whole of government accounts'. ${ }^{4}$ However, as consolidated accounting represents several organisational challenges, there are also

\footnotetext{
1 Santis; Grossi and Bisogno (2019), p. 1.

2 Aggestam-Pontoppidan and Andernack (2016), p. 308.

3 J.P. Morgan is attributed to have insisted on consolidated accounts for his steel holding company in 1901, see Mueller; Gernon and Meek (1997), p. 103.

4 See Brusca and Montesinos (2009), p. 243.
} 
some jurisdictions that withdrew the legal requirement for consolidated financial reporting in the public sector, e.g. for their local governments. This is the case e.g. in some federal states in Germany, in which small local governments do not need to prepare CFS anymore. ${ }^{5}$ This has been explained with the reason that the costs for preparing the CFS do exceed the benefits of having consolidated data. Still, both practice and research are predominantly of the view that CFS foster accountability and support decision-making 6 as will be addressed in Subsection 3 of this chapter.

The aim of Chapter 12 is to introduce important terms with respect to CFS, which are to some extent comparable with the private sector, but also to highlight specific issues related to the public sector. Chapter 13 is instead devoted to consolidation methods relevant for IPSAS CFS. Thereby, both chapters take accrual-based financial statements as starting points. This chapter does not deal with aggregations used for a consolidated presentation of budgets neither building on the cash principle nor on the accrual principle. ${ }^{7}$

This Chapter 12 is structured as follows: Section 2 introduces the group as one fictional entity and the consolidation scopes, followed by Section 3 with reasons for consolidated accounting and theories of consolidation. Organizational challenges for setting up consolidated accounts are discussed in Section 4. The often debated question, how the reporting entity is to be defined and what are the boundaries of consolidated accounts, in particular with respect to the public sector, are in the focus of Section 5. Section 6 generally introduces the methods and procedures of consolidation, which are again addressed in Chapter 13 with IPSAS-based examples. Finally, a conclusion is provided in Section 7 together with a comparative table showing the status quo of consolidated financial reporting in the DiEPSAm partner countries.

5 For instance in the German federal state Mecklenburg-Vorpommern https://www. regierung-mv.de/Aktuell/?id=147126\&processor=processor.sa.pressemitteilung

6 See e.g. Chapter 8 for the terms accountability and decision-making support.

7 See Bergmann et al. (2016), p. 772 for a short explanation of cash-based traditional approaches. 


\section{The group as a fictional entity and the consolidation area}

The concept of an economic entity is based on the fiction that single entities, which are legally independent, from an economic point of view represent one entity. The idea of the fictional entity assumes that the single entities belonging to the group fictitiously lose their legal independence and are treated in accounting as legally dependent operations. Thereby, an economic entity (i.e. group) is created. Still, this group is neither legally existent nor subject to tax law. ${ }^{8}$ Also, in a public sector context, Clarke and Dean (1993) stress that groups of governments with their controlled entities are "a fictitious structure, without legal power to exercise rights or incur physical or financial damage. " 9 In this context, it needs to be stressed, that the idea of the fictional accounting entity is not to be confounded with the entity theory, which is explained in the next section.

With respect to the composition of a group, the consolidation area - also called scope of consolidation - is to be clarified. Building on the approach adopted by private sector accounting, usually it is defined depending on the degree of influence exercised by the controlling (i.e. parent) entity. Chapters 12 and 13 of this textbook draw on the concept of control as the leading principle to define the scope of consolidation, because it is the principle predominantly used in the European public sector accounting (PSA) context. However, using the concept of control is not uncontested in public sector research and practice, as Section 5 of this chapter will address in more detail.

\footnotetext{
8 Küting and Weber (2018), p. 92.

9 Clarke and Dean (1993) cited by Grossi et al. (2014).
} 


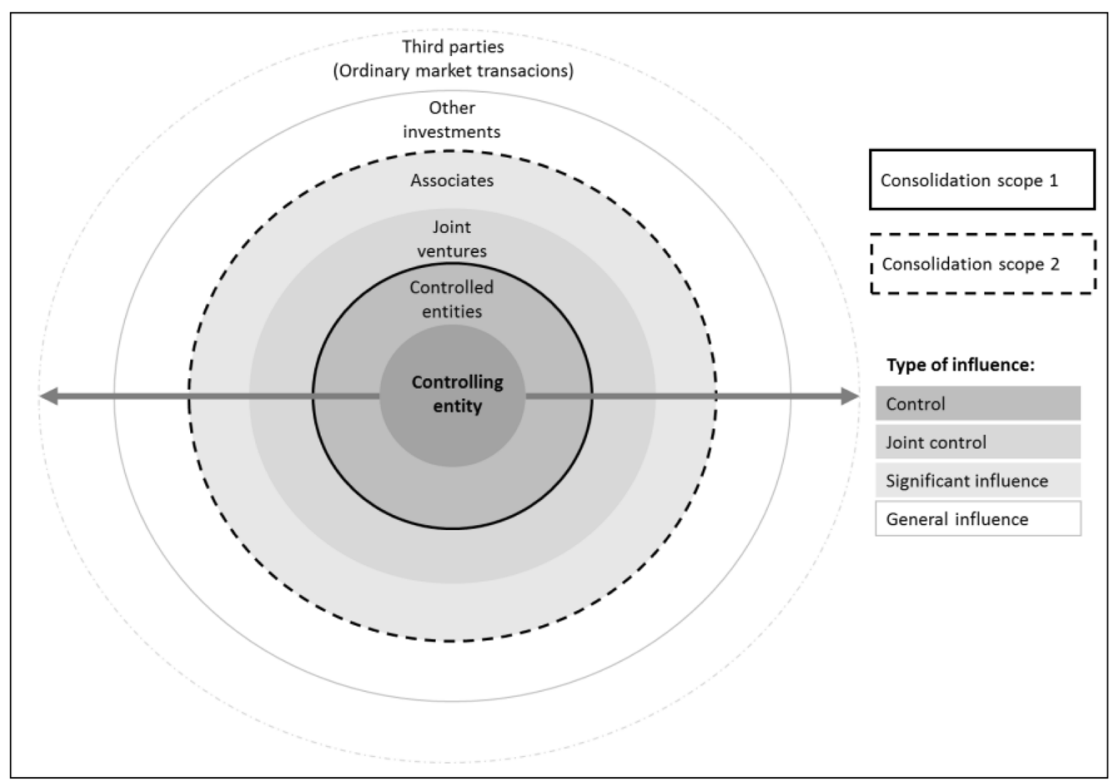

Figure 12.1: Scope of consolidation - between bierarchy and market

In a narrow sense, the scope of consolidation 1 (see Figure 12.1) encompasses the parent entity and the entities that are only controlled by this entity. Control is seen as the strongest form of influence of one entity to another. Although the concept of control is internationally accepted and applied in order to identify the consolidation area, there is no common definition. ${ }^{10}$ In terms of voting power (if applicable) the parent is presumed to have more than 50 percent of the voting power of an investee. Depending on the control pattern, control can be exerted either directly from the controlled to the controlling entity, and/or indirectly. A mixed direct and indirect control might be based on the total of voting rights, owned directly by a parent of the group and owned indirectly by at least one other controlled entity. The third scenario is an indirect control. In these cases, the economic entity consists of more than one chain of controlling relationships, which means, that a controlled entity holds control of another entity, i.e. it is itself a controlling (parent) entity. Such indirect control is also called pyramiding control. In any cases, the highest level

10 See also Brusca and Montesinos (2009). 
entity (the ultimate parent) includes financial information from all directly and/or indirectly controlled entities into a single set of CFS.

The consolidation area can also be viewed in a broader sense (scope 2), which also encompasses two types of non-controlled entities. Thereby, weaker but sufficient influence by the parent entity must be given to include also joint ventures and associate entities.

Joint venture mean that an entity together with at least one entity outside the group jointly and unanimously controls another entity. The jointly controlling entities share rights to the net assets of the joint venture. ${ }^{11}$

An associate is given, if the controlling entity holds a significant influence in another entity. Significant influence is prevalent if the parent entity does not have control over another entity, but it has a reasonable share in this entity. ${ }^{12}$ This share provides influence to participate in the operating and financial policy decisions of an entity, but it is not control over those policies. In terms of voting power (if applicable) the investing entity is presumed to have significant influence, if it holds at least 20 percent of the voting power of an investee, but not more than 50 percent.

If the influence is weaker, (almost) normal 'business' (market) relationships are assumed, so that no consolidation techniques are required. Such investments are included in the CFS as financial assets as in the FS.

The consolidation area described above is primarily drawn from private sector accounting. However, using the private sector approach to identify the scope of consolidation in the public sector can lead to several practical problems as raised by e.g. Grossi and Steccolini (2015) and Bisogno et al. (2015). Depending on how the relationship between one entity and another is defined (e.g. either controlling, joint control or significant influence or none) the method of consolidation might differ. Typically, (depending on the accounting standards applied) controlled entities are fully consolidated, whereas associated entities or joint ventures are not. This

11 For the distinction between joint operations and joint ventures as variants of joint arrangements, see Chapter 13.

12 Krimpmann (2015), p. 67. 
can lead to a "negative effect in terms of financial disclosure" in cases of entities with "fragmented or mixed public-private ownership" as the assets and liabilities of associates and joint ventures are not shown in the CFS, although a public sector entity is retaining financial responsibility. ${ }^{13}$ Before the consolidation methods are explained, the objectives and theories of consolidation and the challenges of preparing CFS are addressed.

\section{Theories and objectives of consolidated accounts}

Accounting theories have already been addressed in Chapter 5 by explaining that these represent "a set of broad principles that provide a general frame of reference by which accounting practice can be evaluated and guide the development of new practices and procedures". With respect to accounting theories, that can serve as a reference for consolidation, the (1) entity theory, (2) parent company theory and the (3) proprietary theory are relevant, which are popular accounting approaches in the private sector, but are also discussed in the public sector context. ${ }^{14}$ These three theories refer rather to the technicalities of consolidation and in particular provide guidance on how non-controlling interests (also called minority interests) are to be treated. Non-controlling interests specify the remaining interest in net assets that is held by outside investors in controlled entifies, but not by the controlling entity. In research, there are also other theories that are relied upon in order to discuss users and usefulness of CFS, such as the legitimacy, institutional, agency, or stakeholder theory. ${ }^{15}$ Still, a basic accounting theory for explaining the research in this field so far has not been found. ${ }^{16}$

According to the (1) entity theory, the controlled entities are regarded as dependent permanent operations of the parent. Entity theory takes the perspective of the economic entity itself, separated from its

\footnotetext{
13 Grossi and Steccolini (2015), p. 330.

14 See also Chapter 5.

15 Santis; Grossi and Bisogno (2018).

16 See Santis; Grossi and Bisogno (2018), p. 238 with reference to other papers.
} 
owners. Consequently, both the owners of the parent entity and all (minority) owners of non-controlling interests of the controlled entities are 'shareholders' of the economic entity. This perspective serves for all considerations of classification, valuation and netting the assets and liabilities of the controlling and the controlled entities. However, the scope of application of the entity theory is generally limited to the CFS. For relationships with third parties (shareholders (if applicable), creditors, and tax authorities), the individual FS remain decisive, so that intra-entity offsetting has no legal effect. Entity theory is seen as "fundamental to modern accounting as well as more appropriate, especially in the public sector" than the parent company theory, which is explained subsequently. ${ }^{17}$

(2) Parent company theory takes the viewpoint of the controlling (parent) entity in order to represent the economic entity in the CFS. According to this view, the controlling entity has the power to control the assets and liabilities of other entities to the full extent, i.e. not only with a proportionate share. A full consolidation approach is applied by separately recognising the claims on the net assets of non-controlling interests as a kind of liability and the claims of the non-controlling interests in the surplus or deficit as income or expenses. ${ }^{18}$ When the individual FS are aggregated, positions in the balance sheet and income items (or cash flows) are to be split into claims inside and outside the economic entity.

From the point of view of (3) proprietary theory, the economic entity is defined narrower than according to the previous two theories. Thus, the CFS has the function of an extended FS of the controlling entity. The extension relates to the items of the balance sheet, income statement and cash flow statement, to which the controlled entity is (proportionately) entitled. As a result, the non-controlling interests are to be regarded as liabilities, their pro rata profits for the period as expenses and their pro rata inter-entity profits as realised from the point of view of the controlling entity. CFS prepared in accordance with the proprietary theory therefore do not provide a complete insight into the net assets, financial position and results of operations of the

17 See e.g. Bisogno et al. (2015), p. 312.

18 See e.g. Bisogno et al. (2015). 
group (as controlled by its ultimate parent). From an economic perspective, it is regarded as an inappropriate information and decision-making tool. ${ }^{19}$

Depending on the theory, also the objectives of consolidated financial reporting differ. Based on the entity theory, the CFS have a pure information function. They are intended to provide a true and fair view of the group's position. In contrast, according to some national accounting standards, SFS also have a profit/revenue distribution function. In particular in the municipal context, the increase in service delivery by public corporations hampers the financial transparency of FS of local governments as the reports only represent a partial view of the municipalities' economic and financial activities, as the financial consequences of controlled entities, joint ventures, and associates are not adequately considered. ${ }^{20}$

The objective of CFS is seen to "provide relevant and undistorted financial information to internal and external stakeholders that encompasses every subsidiary or department and clears out any internal transactions, as well as mutual assets and liabilities". 21 To offer such view, CFS are argued to be necessary also in the public sector context. ${ }^{22}$ However, Walker (2009) warns that other financial statements or budget reports might be more suitable for some information needs, e.g. to inform about efficiency of service delivery. Based on theoretical considerations, Walker (2009) lists the following routinely made judgements, for which CFS prepared at the central government level might deliver the necessary (decision useful) information: ${ }^{23}$

1. Results and sustainability of a government's financial management practices;

2. Capacity to continue to deliver existing levels of services (or to enhance those services);

3. Manner in which government is pricing services;

\footnotetext{
19 See e.g. Bisogno et al. (2015).

20 Tagesson (2009).

21 Bergmann et al. (2016), p. 766.

22 See e.g. Heald and Georgiou (2000) and Lande (1998).

23 See Walker (2009), p. 200, Table 3.
} 
4. Extent to which a government is funding or delivering subsidised services;

5. How government has spent taxpayers' funds and any borrowings;

6. Whether a government is incurring obligations which will impose burdens on future generations;

7. Attractiveness of investing in government securities;

8. Attractiveness of maintaining investment in government securities;

9. Financial circumstances of regional governments vis-à-vis other regional (state) governments; and

10. Financial circumstances of nations vis-à-vis other nations.

However, it needs to be stressed that these points refer to a special category of CFS and do not apply to CFS at all government levels. Thereby, Walker (2009) also stresses and criticises, that the users and addressees of CFS need to be identified first in order to figure out their information needs and thus to adjust the objectives of CFS. He suggests that even several kinds of CFS might be necessary depending on the information needs. This means that even multi-column CFS might be required, e.g. the first column entails information about primary government, further columns provide aggregated data about different segments of the group and a final column provides information about the entire group.

The addressees and users of public sector CFS are strongly debated in practice and research. ${ }^{24}$ Usually, the following users/stakeholders are discussed to benefit from the CFS by greater transparency and better support for decision-making processes: internal users such as politicians, managers, and employees and external stakeholders such as citizens, voters, taxpayers, suppliers, other public administrations, and financial institutions. ${ }^{25}$ For internal users, CFS can represent a tool for "steering and controlling the direct and indirect provision of public services" and "public decision-making and programming and controlling the different public policies". 26 With respect to external stakeholders, banks can use CFS

\footnotetext{
24 See e.g. Walker (2009) and Bergmann et al. (2016).

25 Santis; Grossi and Bisogno (2018), p. 242.

26 Bergmann et al. (2016), p. 766.
} 
in order to assess creditworthiness of the economic entity and for rating agencies, CFS are useful to assess solvency and financial risks. ${ }^{27}$ However, empirical findings about the actual usefulness are sparse. ${ }^{28}$

\section{Organisational challenges}

The compilation and presentation of CFS can be an organisational challenge because it contains a range of steps to be conducted. This process may also depend on the legal requirements, i.e. the jurisdiction the public sector entity is located in. In the following, a (non-exhaustive) enumeration of challenges with a particular focus on the public sector context are listed and explained subsequently: ${ }^{29}$

1) Implementation of consolidated financial reporting;

2) Initial consolidation;

3) Requirement of uniformity;

4) Timely organisation of the consolidation process;

5) Coordination of audits.

The (1) implementation of consolidated financial reporting needs to be well prepared before its start. Consolidated financial reporting can be considered to be the supreme discipline of accounting and financial reporting, because it concerneds all kinds of economic transactions on several layers of an economic entity. Therefore, skilled personnel are needed, which are experienced in applying the consolidation methods and able to oversee the relevant consolidation areas in the economic entity. As such, in particular for the public sector, there is a high demand for qualified personnel. This also means that enhanced personal costs, costs for training and consulting are incurred. The volume of data for consolidated accounting and the time required for its transfer generally lead to the need

\footnotetext{
27 Bergmann et al. (2016), p. 766.

28 Walker (2009); Bergmann et al. (2016).

29 See also Krimpmann (2015) or Lorson; Poller and Haustein (2019) for more detailed explanations.
} 
for enhanced information technology systems and the respective accounting software. 30

In particular, with respect to (2) initial consolidation in the public sector, the determination of its date can be in question. Of course, this date will also depend on national or local accounting standards and an obligation to present CFS and also on the necessary aforementioned preparations. The date of initial consolidation is relevant for the revaluation of the assets and liabilities of the newly consolidated entities. In the public sector, in particular when initially starting with consolidated accounting, in most cases the acquisition transaction of the controlled entity will be fictitious. In addition mostly, an entity does not only become a controlled entity at the point in time when it is included in the CFS, but before, when the controlling (parent) entity obtains control. This is particularly the case in countries in which accrual accounting is just adopted. In this respect, a focus on the time of acquisition is associated with considerable problems with regard to revaluation of assets and liabilities at fair value as of the acquisition date.

Preparing CFS involves specific (3) requirements of uniformity, i.e. that the FS of the consolidated entities are based on the same criteria with respect to recognition of items, measurement and structure. ${ }^{31}$ However, a particular challenge to achieve is the harmonisation of the FS of the different decentralised entities drawn up according to different accounting standards. ${ }^{32}$ A particular public sector problem is when some entities still use cash accounting, whereas other entities in the group use accrual accounting. Such problem is hardly to overcome. ${ }^{33}$ In addition, whereas a local government entity might use PSA standards, its controlled entities could be private sector entities, which are based upon private sector accounting standards. This would lead to differences in, for example

30 Bergmann et al. (2016), p. 766.

31 See e.g. Walker (2011) with an in-depth analysis of differences in the (non-)recognition and valuation between the jurisdictions, consolidated in the Australian government financial report.

32 Brusca and Montesinos (2009).

33 Brusca and Montesinos (2009). 
measurement of assets and liabilities or in reporting dates. Therefore, the FS of the entities to be included in the CFS need to be prepared before consolidation, which can lead to three levels of FS (in particular with respect to the balance sheet (BS) and income statement):

- FS I: prepared according to local (national) accounting standards;

- FS II: prepared according to accounting standards applied within the economic entity and aligned to the same balance sheet date (if applicable: according to a group individual consolidated accounts manual);

- FS III: of the controlled entities after revaluation, i.e. revealing and amortisation of hidden reserves and burdens. ${ }^{34}$

At the date of consolidation, controlled entities, joint ventures and associates will have prepared FS I (local FS) according to their national accounting standards. In order to establish conformity of the FS of all entities belonging to the economic entity, the consolidated entities need to prepare additional FS II for harmonization, if the accounting standards applied in the FS I do not comply with the standards applied for the CFS. For this purpose, the controlling entity might use a consolidated accounts manual in order to ensure completeness of the accounting approach and uniformity of valuation e.g. by prescribing in which way generally existing recognition, valuation or disclosure options are to be exercised. The consolidated accounts manual serves as a guideline for the consolidated entities and incorporates the uniform balance sheet date, accounting, disclosure and measurement methods for the economic entity. It may consider structures in the economic entity, reporting structures and the accounting environment and may also prescribe a chart of accounts to be used. Those guidelines will vary between different groups because of individual decisions in fields, where options and management judgement has to be exercised. Due to the complexity of the issues to be prescribed, the consolidated accounts manual should be documented in writing (at least

34 See also Chapter 13. 
in the group's main language) and agreed with the body of audit. If even foreign controlled entities are involved, binding regulations must be made regarding language (of the report and communication for reporting) and currency conversion.

A further challenge can lie in the (4) timely organisation of the consolidation process. Being able to comply with the preparation, auditing and disclosure obligations is to be strictly organised with respect to the time horizon and possible deadlines for reporting and auditing. A binding timetable should be drawn up and enforced for all entities in the scope 1 and 2 of consolidation in order to ensure timely preparation.

Finally, with respect to the (5) coordination of audits, national or local audit law needs to be adhered to when setting up CFS. The audits of the FS of the controlled entities, joint ventures and associates must be coordinated with the audit of the CFS.

These challenges include one-off issues (e.g. the preparation of the consolidated accounts manual) and recurring issues such as the maintenance of the consolidated accounts manual on the basis of a monitoring of changes to accounting standards in conjunction with an assessment of the associated changes, e.g. the maintenance of schedules and the generation, evaluation and audit of data.

\section{Scope and boundaries of consolidated accounts}

The consolidation area, i.e. the type of entities to be included in CFS, has already been explained in Section 2 . It is a critical and also highly debated topic in the public sector context. Further issues, which are explained in this section, are the criterion to define the consolidation area (i.e. the control concept) and the definition of the reporting unit. Both of these aspects also influence the scope and boundaries of consolidated accounts.

In Section 2, the scope of consolidation was distinguished based on the concept of control. This means that an organisational and legal perspective is applied. Still, control is differently defined in national and international accounting standards, which in turn can lead to differences 
in the composition of the group. Mostly, control is based on ownership or rights to exercise power based on a substance-over-form control relationship as in the case of IFRS 10 and IPSAS 35. Whether control is prevalent, also depends on the national law and the government structure. In some countries, the general government might have control over its states and local governments, whereas in other countries due to different legal settings such control is not given. Also, in the public sector context, the definition of control can be critical if distinguishing between market versus political forces. For example, entities, which are economically dependent on a public sector organisation due to being funded through the government budget, are not considered controlled and not consolidated in IPSAS CFS, as mere budget dependence is not seen as a sufficient indicator of control according to IPSAS 35.26b.

The example of budget dependence, i.e. economic dependence, shows that the control concept is not the only criteria that can be used for defining the scope of consolidation. In particular in the public sector, other perspectives and approaches could be appropriate to define the scope of consolidation, for example a so-called statistical perspective, a risk perspective or a budget or budgetary perspective. ${ }^{35}$ For example, in the USA, the consolidation area is defined based on financial accountability and budget dependence and in Sweden organisational law is the basis. ${ }^{36}$ Still, the control concept is predominantly relied upon in Europe and also in the DiEPSAm partner countries as the comparative Table 12.1 shows.

Besides the concept of control, the definition of the reporting unit is strongly linked to the consolidation area. More generally, it refers to the question, which government levels are to be included in one economic entity and which entities to exclude. On the most general level, consolidated accounts and whole of government accounts can be distinguished in this context. In some countries, such as Portugal or Finland, CFS are prepared for the single economic entities in the country (e.g. single local governments or the central government). These are also called individual consolidated

\footnotetext{
35 See Bergmann et al. (2016), p. 769 for a detailed description of the perspectives.

36 Bergmann et al. (2016), p. 773.
} 
accounts. ${ }^{37}$ In other countries, a broader approach is applied, which is also known as whole of government accounting (WGA) or whole of government financial reporting (WGFR). WGFR is not very widespread, but only applied by few countries. ${ }^{38}$ In the UK or in New Zealand, the process of consolidation includes all of the different levels of government, and for the case of the UK even the public corporations. WGFR aims to present "the overall financial position of the government of a particular jurisdiction [...] via the consolidation of the financial statements and transactions of all the entities controlled by the jurisdiction's government"39 by producing "statements encompassing the whole of a specific tier of government". 40 The process of WGFR is very data intensive and complex. ${ }^{41}$ In particular for countries organised as federal states, WGFR is argued to be very challenging, but "less useful". 42

Comparisons are often drawn between WGFR and government financial statistics (GFS). ${ }^{43}$ GFS focuses at the general government sector ${ }^{44}$ and provides macroeconomic information concerning each of the different sectors of the economy. To some extent, the GFS also present a consolidated view of the different sectors of the economy, and thereby also produce a consolidated view of the general government sector. But as control is not the guiding principle for defining the boundaries of consolidation, GFS do not produce the same type of data as CFS or WGFR, given that the latter are based on the concept of control. ${ }^{45}$ Figure 12.2 shows the financial reporting entity from a macroeconomic point of view, with its differentiation between the general government sector and public non-financial and financial

\footnotetext{
37 Chow et al. (2015), p. 6.

38 Brusca and Montesinos (2009), p. 243.

39 Santis; Grossi and Bisogno (2018), p. 231 with further references.

40 Walker (2009), p. 173.

41 Brusca and Montesinos (2009).

42 Bergmann et al. (2016), p. 776.

43 See Chapter 6 for more details.

44 See Chapter 1 for a definition.

45 Bergmann (2009).
} 
corporations (in bold rectangles). ${ }^{46}$ CFS also include controlled public nonfinancial and financial corporations. Due to these differences in the entities included, there are attempts to harmonise macroeconomic GFS and micro economic accounting, e.g. in Australia. ${ }^{47}$

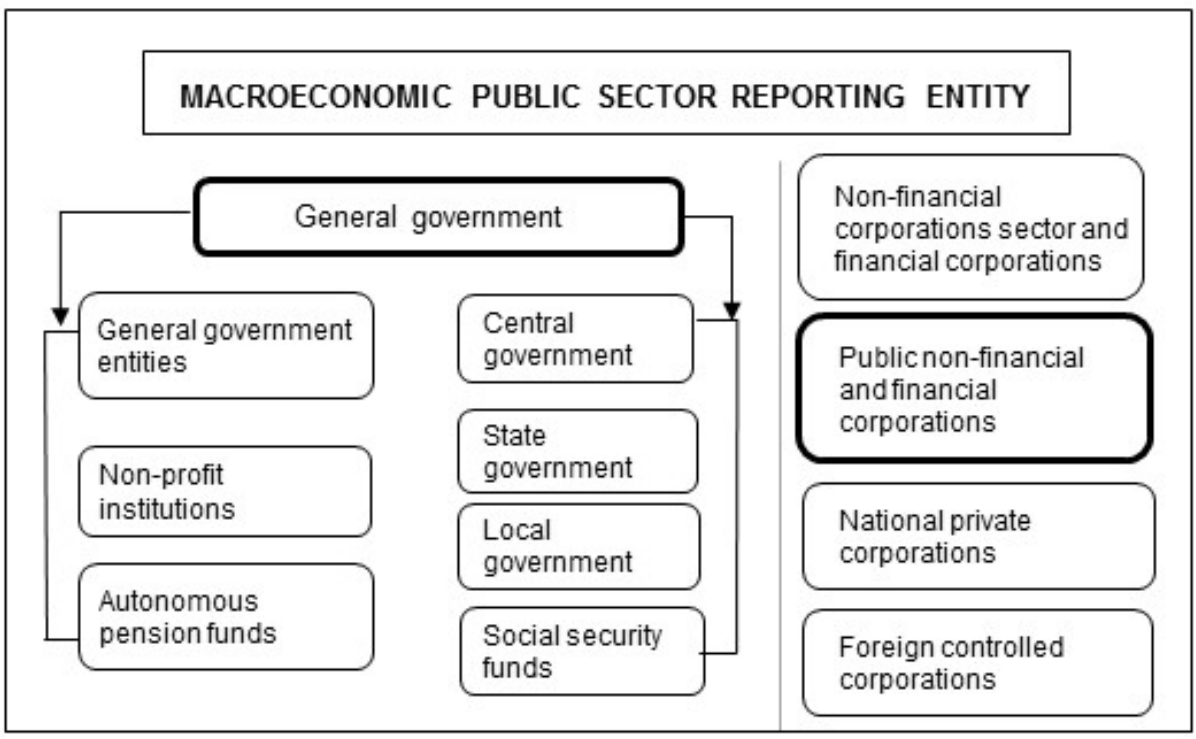

Figure 12.2: Macroeconomic public sector reporting entity

(Source: Brusca and Montesinos, 2009)

Even in those countries that produce WGFR, several differences lead to the fact that the reports would not be comparable because the definition of the reporting entity differs. ${ }^{48}$ Thus, there are disparities of what is encompassed by WGA as shown in Figure 12.3, reflecting different ways of defining WGFR.

\footnotetext{
46 See Brusca and Montesinos (2009) for more detailed explanations.

47 Brusca and Montesinos (2009), p. 247.

48 Brusca and Montesinos (2009), p. 243.
} 


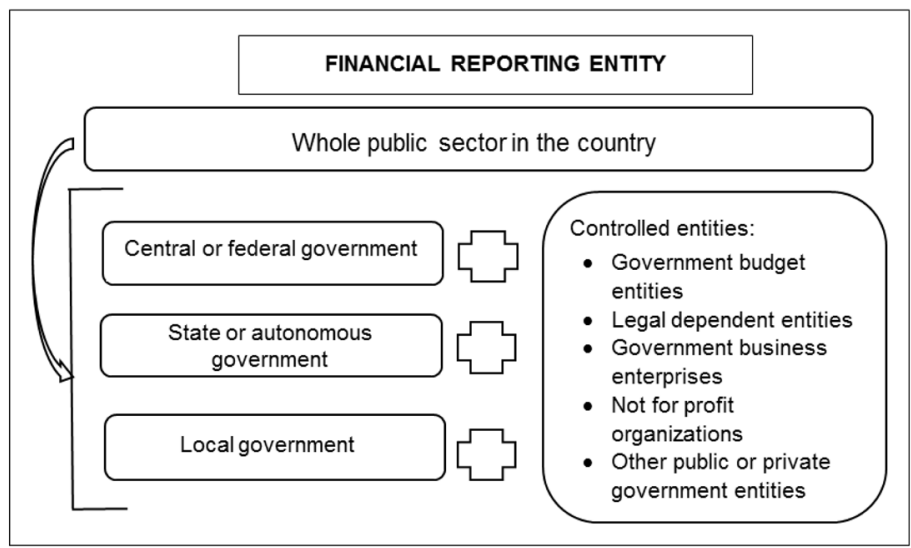

Figure 12.3: Financial reporting entity (Source: Brusca \& Montesinos, 2009)

In the UK, the whole of government accounts are seen as the "most consequent approach to CFS". These comprise all state levels and public corporations. Notable exclusions are that the Parliament and the National Audit Office are not included in the consolidation area in order to stress in particular the Parliament's role in holding government to account. Also in the UK WGFR, nationalised banks are not consolidated. ${ }^{49}$

The question whether also to consolidate entities that have dissimilar operations compared to the controlling entity - such as banks -, is highly contested and does not only refer to WGFR, but also to individual CFS. To include entities with "strong balance sheets", e.g. national banks, financial intermediates or insurances, as controlled entities by full consolidation would mean that all the assets of those entities are shown in the consolidated balance sheet. This could lead to misinterpretations of the CFS in terms of high resources of the economic entity. Therefore, such entities with dissimilar activities are e.g. in Canada not fully consolidated, but included according to the equity method or in Austria or France not included in the CFS at all. ${ }^{50}$ In such cases, divergence from full consolidation could be reasonable.

\footnotetext{
49 Chow et al. (2015).

50 Bergmann et al. (2016), p. 779.
} 
Overall this section showed that there is no ultimate solution for the definition of the reporting entity and the scope of consolidation. As such, there will be differences between the CFS of different public sector entities on an international scale.

\section{Methods and procedures of consolidation}

As highlighted in Section 2, Figure 12.1 depending on the type of influence and also the accounting standards, different methods of consolidation are to be used. The consolidation method refers to the procedure used in the preparation of CFS and the inclusion of entities in the CFS. The following three methods are introduced below subsequently, 51 followed by an explanation of the procedures of consolidation needed for the full consolidation method:

1) Full consolidation;

2) Proportional consolidation and

3) Equity method.

In the case of (1) full consolidation (also called line-by-line consolidation), the assets, liabilities and net assets/equity as well as the revenues and expenses of the controlled entities are included in full in the CFS on a line-by-line basis, irrespective of the controlling entity's share in the net assets of the controlled entities. For non-controlling interests, an adjustment item must be formed for the amount of their portion in net assets in the consolidated balance sheet. Accordingly, in the consolidated statement of financial performance, the share of surplus or deficit attributable to non-controlling interests included in the net surplus or deficit for the reporting period must be disclosed. Transactions between the entities are to be eliminated in full. This includes offsetting of mutual liabilities (and receivables) and elimination of both double counting and economic

51 See e.g. Mori (2016) and Krimpmann (2015) for detailed explanations. 
transactions not yet realised with third parties. As such, full consolidation requires consolidation of net assets/equity, debt intra-economic entity revenues and expenses and the elimination of interim results. These consolidation procedures are explained at the end of this section.

When applying (2) proportional consolidation, the assets, liabilities and net assets/equity of the controlled entities as well as the revenues and expenses are only included the CFS, to the extent of the controlling entity's portion in the net assets of the controlled entities. Also here, similar items in the FS are combined, but only to the extent "owned" by the controlled entity, e.g. 60 or 80 percent of a piece of land or a building or a provision. Non-controlling interests are excluded from the CFS, so that only the controlling interest of the parent entity in other entities is shown.

Strictly speaking the (3) equity method is not a method of consolidation. Depending on the national accounting standards, it is a commonly used method of integrating associates and joint ventures - and in the case of Germany also (because of non-materiality) non-consolidated controlled entities - into the CFS. When applying the equity method, the shares of an entity are initially recognised at cost and in subsequent periods adjusted for the post-acquisition change in the reporting entity's portion in the net assets/equity of the entity. ${ }^{52}$ Thus, the assets and liabilities of entities included by the equity method are not shown in the CFS.

The aim of full consolidation is that the CFS appears as if the consolidated entities were actually a single entity. This implies that all intra-economic entity transactions need to be eliminated. Full consolidation encompasses four different consolidation procedures, which are shortly explained in the following by highlighting public sector specifics; examples are shown in Chapter 13:

1) Net assets/equity consolidation;

2) Debt (and receivables) consolidation;

3) Revenue and expenses consolidation and

4) Elimination of unrealised gains or losses.

52 Bergmann et al. (2016), p. 771. See example provided in Chapter 13. 
(1) Net assets/equity consolidation is also known as capital consolidation. The purpose is to prevent the equity of the controlled entity from being recorded twice, by offsetting the carrying amount of the investment of the controlled entity against the controlling entity's share of the equity of the controlled entity. If the carrying amount of the investment does not equal controlling entity's share of the equity, the difference is to be accounted for as either goodwill or badwill. Different methods are available for this area of consolidation, e.g. the acquisition methods, the pooling of interest method or the fresh start method with differences regarding revaluation of the consolidated entities' assets and liabilities ${ }^{53}$ as depicted in Table 12.1.

\begin{tabular}{|l|c|c|}
\hline \multicolumn{1}{|c|}{ Entity } & Controlling entity & Controlled entity \\
\hline \multirow{2}{*}{ Valuation of assets/liabilities } & \multicolumn{2}{|c|}{1 Fair value } \\
\cline { 2 - 3 } & \multicolumn{2}{|c|}{2 Book value } \\
\hline Pooling of interest method & 2 & 2 \\
\hline Acquisition (or purchase) methods & 1 & 1 \\
\hline Fresh start method & 2 & 1 \\
\hline
\end{tabular}

Table 12.1: Differences in valuation between the methods of net assets/equity consolidation

Net assets/equity consolidation is the first step when initially consolidating controlled entities and exemplified in Chapter 13.

In the course of (2) debt consolidation, intra-entity receivables and liabilities as well as all other loans, provisions and corresponding prepaid expenses must be eliminated. The aim is to avoid double counting and thus to eliminate the annual effect of intra- entity debt relationships on the net asset situation. In the simplest case, the items with the character of mutual receivables and payables are mirrored (in the same amount) with no offset differences. Such debt relationships are neutralised by simply "omitting" them (without affecting surplus or deficit). Debt consolidation must be

53 See Munter (1999) for an explanation of the methods. 
(partially) recognised in surplus or deficit, if offset differences arise because liabilities and receivables have different amounts. A distinction can be made between "real" and "unreal" offset differences: 54

- Real offset differences arise from different recognition and measurement rules, which are not eliminated by an adjustment to uniform accounting rules in the course of preparing the FS II.

- Unreal offset differences, are based on accounting deficiencies, i.e. these arise due to timing differences in the booking of those transactions in the accounts of the engaged entities or incorrect accounting records and should therefore be corrected before the CFS are prepared.

The aim of (3) revenue and expenses consolidation is to take account of the principle of realisation: Revenue and expenses may only be recognised, if they have been realised vis-à-vis third parties outside the economic entity. All other (intra-economic entity) supply and service relationships, interest expenses and income as well as income from investments are to be treated - in accordance with the entity fiction (see Section 2) - as relationships between dependent operations. Hence, revenue and expenses must be consolidated, unless these are related to increases in inventories or own capitalised work. Depending on the local accounting standard, revenue and expenses consolidation may be omitted if it is of minor importance for the CFS. If corresponding revenue and expenses of the same amount are offset against each other, they are to be treated in the same way as described for debt consolidation, i.e. these are to be written off against each other. The treatment of offset or netting differences is as explained for debt consolidation.

A particular offset difference in the public sector can result from sales tax. The consolidation of economic transactions, in which one entity is subject to sales tax and the other entity is not eligible for sales tax deduction, is largely unclear. Various solutions are applied and discussed

54 See Krimpmann (2015), pp. $278 \mathrm{ff}$. 
in practice. For example, it is possible that the offset difference remains in the consolidated expenses or that the offset difference is eliminated via the other expenses. 55

A public sector specific case of revenue and expenses consolidation is tax consolidation, i.e. if one of the consolidated entities pays tax to another consolidated entity (e.g. a local authority). ${ }^{56}$ To prepare CFS, tax revenue (or expenses from tax refunds) of the local authority must be offset against the corresponding tax expenses (or income from tax refunds) of the entities to be consolidated. Special features for tax consolidation arise, e.g. from combined federal, state and local taxes: One public sector entity is entitled to collect these taxes, but the tax is shared between public sector entities at different government levels on a pro rata basis. Combined federal, state and local taxes can be shown as liabilities from tax distribution. A further challenge in tax consolidation arises from different recording and realisation dates for the consolidated entities. These can result from the imparity (of revenue and expenses recognition) principle, for example, in the case of corporation tax: While the paying entity must recognise the corporation tax expense as a provision (reduced by advance payments) on the reporting date, the receiving state or federal government may only realise the income from corporation tax once it has been sufficiently specified (e.g. with the publication of the tax assessment notice). Due to the recognition as a provision by the paying entity and the missing recognition of a receivable in the receiving entity, offset differences regularly arise, which must be eliminated in the course of consolidation with an effect on surplus or deficit in the CFS.

A further specific public sector application of this procedure of consolidation refers to the consolidation of grants, depending on how grants are recorded by the grant provider and recipient. Investment grants can lead to an asset item for one of the entities involved and a liability item for the second entity involved. Within consolidation, these two items are to be eliminated and accounting records to release the item (intangible assets)

\footnotetext{
55 See e.g. Lorson et al. (2016), Note 715.

56 See e.g. Lorson et al. (2016), Notes 720 ff.
} 
with an effect on surplus or deficit are to be reversed. In the case of income subsidies, the offsetting is completed analogous to the consolidation of revenue and expenses.

Finally, the 4) elimination of unrealised gains or losses is to be carried out. Gains and losses based on inter-economic entity deliveries and services that have not yet been realised with third parties must be eliminated from the CFS unless they are of minor materiality. To this end, the valuation of these assets must be adjusted. There may also be a requirement to eliminate interim results for entities which are included in the CFS using the equity method. Like for the other procedures of consolidation, an example is shown in Chapter 13.

Usually, no group accounting system for the economic entity will exist. This means, that each reporting period the SFS of the consolidated entities need to be harmonised (SFS II) and prepared for consolidation (SFS III). Then, depending on the type of entity to be consolidated, a respective method of consolidation is to be implemented followed by the steps described for the procedures of consolidation in the case of full consolidation. In each reporting period, these steps are to be repeated until the current reporting period (only in order to establish the status quo), followed by the actual consolidation records for the current reporting period. The application of the equity method is explained in Chapter 13.

\section{Conclusion}

This chapter aims to give an introduction into terms and processes related to compiling CFS. Due to an increase in relationships of public sector entities with other entities, CFS can lead to enhanced transparency and can also support decision-making in the public sector. Although consolidated financial reporting is a complex and quite technical process, it can be seen as an important development in PSA and reporting. However, there are many different approaches regarding the definition of the 
consolidation scope, the definition of the reporting unit and differences in the application of the consolidation methods on an international scale.

As a summary of this chapter, Table $\mathbf{1 2 . 2}$ provides an overview about consolidated financial reporting in the DiEPSAm partner countries. Like for the status quo of individual financial reporting shown in Chapter 1, the current situation is quite heterogeneous. However, commonalities lie in the definition of the consolidation area according to the control concept. As stressed in this chapter, the UK can be seen to pursue the most consequent approach to CFS (WGA). Chapter 13 continues to explain consolidation methods by specifically drawing on IPSAS and giving some example calculations. 


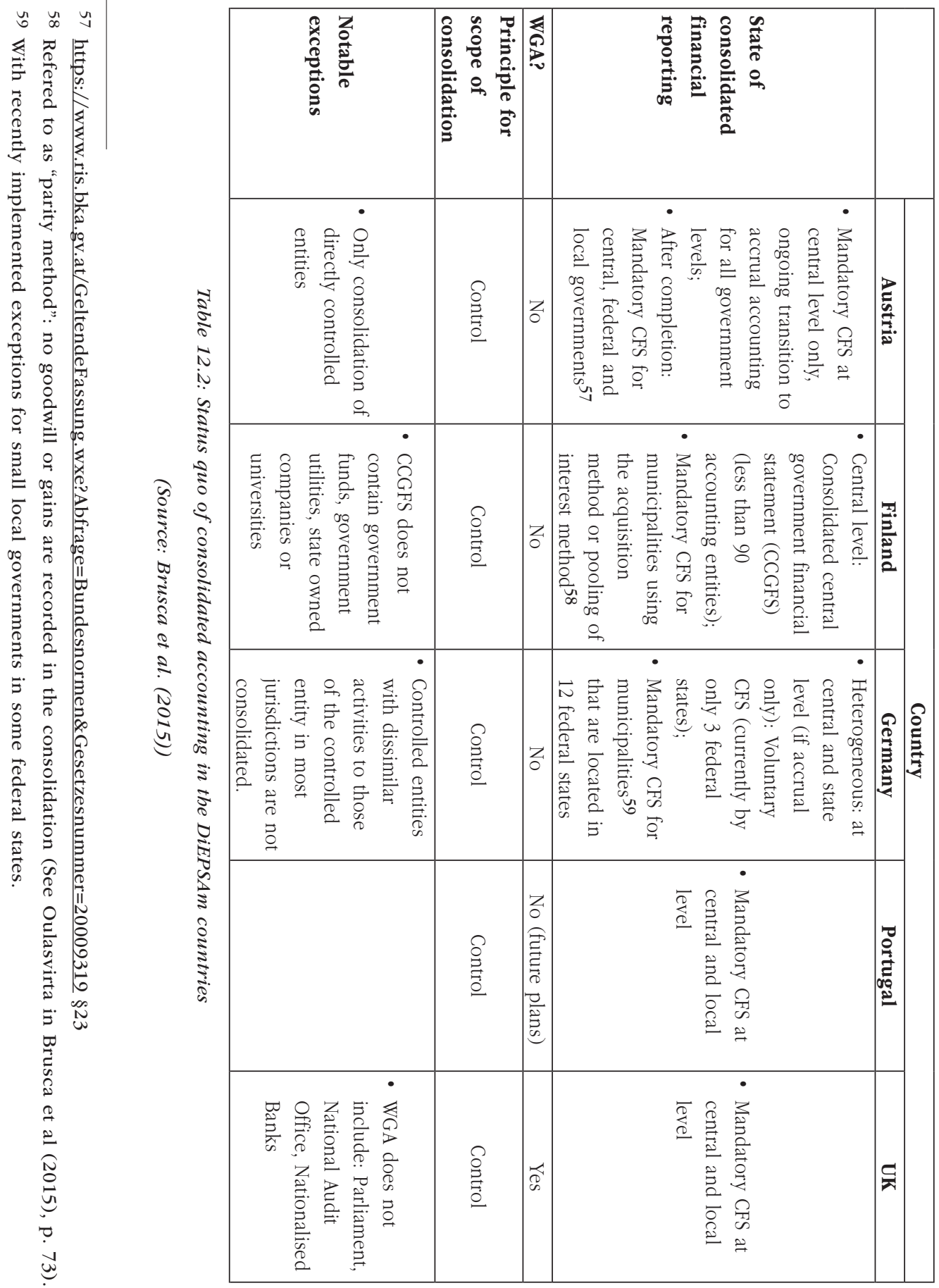




\section{Bibliographic references}

AGGESTAM-PONTOPPIDAN, Caroline and ANDERNACK, Isabelle (2016) - Interpretation and application of IPSAS. Chichester: Wiley, ISBN: 978-1-119-01029-6.

BERGMANN, Andreas (2009) - Public Sector Financial Management, Harlow et al.: Prentice Hall, ISBN: 9780273713548.

BERGMANN, Andreas; GROSSI, Giuseppe; RAUSKALA, Iris and FUCHS, Sandro (2016) Consolidation in the public sector: methods and approaches in Organisation for Economic Co-operation and Development countries. International Review of Administrative Sciences, 82(4), pp. 763-783.

BISOGNO, Marco; SANTIS, Serena and TOMMASETTI Aurelio (2015) - Public-Sector Consolidated Financial Statements: An Analysis of the Comment Letters on IPSASB's Exposure Draft No. 49, International Journal of Public Administration, 38, pp. 311-324.

BRUSCA, Isabel; CAPERCHIONE, Eugenio; COHEN, Sandra and MANES-ROSSI, Francesca (eds.) (2015) - Public Sector Accounting and Auditing in Europe - the Challenge of Harmonization, Basingstoke: Palgrave Macmillan, ISBN: 9781137461339.

BRUSCA, Isabel and MONTESINOS, Vicente (2009) - International experiences in whole of government financial reporting: lesson-drawing for Spain, Public Money \& Management, 29(4), pp. 243-250.

BRUSCA, Isabel and MONTESINOS, Vicente (2010) - Developments in financial information by local entities in Europe, Journal of Public Budgeting, Accounting \& Financial Management, 22(3), pp. 299-324.

CHOW, Danny; DAY, Ronald; BASKERVILL, Rachel; POLLANE, Raili and AGGESTAM, Caroline (2015) - Consolidated government accounts: How are they used?, Association of Chartered Certified Accountants.

GROSSI, Giuseppe; MORI, Elisa and BARDELLI, Federica (2014) - From Consolidation to Segment Reporting in Local Government: Accountability Needs, Accounting Standards, and the Effect on Decision-Makers, Journal of Modern Accounting and Auditing, 10(1), pp. 32-46.

GROSSI, Giuseppe and STECCOLINI, Ileana (2015) - Pursuing private or public accountability in the public sector? Applying IPSASs to define the reporting entity in municipal consolidation. International Journal of Public Administration, 38(4), pp. 325-334.

HEALD, David and GEORGIOU, George (2009) - Whole of government accounts developments in the UK: Conceptual, technical and timetable issues. Public Money \& Management 29(4), pp. 219-227.

KRIMPMANN, Andreas (2015) - Principles of Group Accounting under IFRS. Chichester: Wiley, ISBN: 978-1-118-75141-1.

KUETING, Karlheinz and WEBER, Claus-Peter (2018) - Der Konzernabschluss, 14th ed., Stuttgart: Schäffer Poeschel, ISBN: 978-3-7910-3730-1.

LANDE, Eveline (1998) - The scope of accounting consolidation in the local public sector. In: CAPERCHIONE, Eugenio and MUSSARI, Riccardo (eds.) Comparative Issues in Local Government Accounting. London: Kluver, pp. 227-239. ISBN: 978-1-4615-4581-1.

LORSON, Peter; DOGge, Bianca, HAUSTEIN, Ellen and WIGGER, Christina (2016) Kommentierung zu Standards staatlicher Doppik (SsD), in: HOFBAUER, Peter \& KUPSCH, Max (eds.): Rechnungslegung. Aufstellung, Prüfung und Offenlegung des Jahresabschlusses, Kommentar, 85. Ergänzungslieferung, Bonn: Beck, ISBN: 978-3-08-255800-3.

LORSON, Peter; POLLER, Jörg and HAUSTEIN, Ellen (2019) - Fallstudie zur Rechnungslegung - Vom nationalen Einzelabschluss zum IFRS-Konzernabschluss, Düsseldorf: Handelsblatt Fachmedien, ISBN: 978-394-7711147. 
MUELlER, Gerhard G.; GERNON, Helen and MEEK, Gary K. (1997) - Accounting: An International Perspective, 4th ed., Boston MA: Irwin/McGraw-Hill, ISBN: 0-256-17082-7.

MUNTER, Paul (1999) - Business Combinations: Are You Ready for Purchase Accounting?, Journal of Corporate Accounting \& Finance, Spring 1999, pp. 19-25.

SANTIS, Serena; GROSSI, Giuseppe and BISOGNO, Marco (2018) - Public sector consolidated financial statements: a structured literature review, Journal of Public Budgeting, Accounting \& Financial Management, Vol. 30 Issue: 2, pp. 230-251.

SANTIS, Serena; GROSSI, Giuseppe and BISOGNO, Marco (2019): Drivers for the voluntary adoption of consolidated financial statements in local governments, Public Money \& Management, DOI: 10.1080/09540962.2019.1618072

TAGESSON, Torbjörn (2009) - Arguments for proportional consolidation: The case of the Swedish local government. Public Money and Management, 29(4), pp. 215-216.

WALKER, Robert Graham (2009) - Public sector consolidated statements - An assessment, Abacus, 45(2), pp. 171-220.

WALKER, Robert Graham (2011) - Issues in the Preparation of Public Sector Consolidated Statements, Abacus, 47(4), pp. 477-500.

\section{Additional readings}

BERGMANN, Andreas; GROSSI, Giuseppe; RAUSKALA, Iris and FUCHS, Sandro (2016) Consolidation in the public sector: methods and approaches in Organisation for Economic Co-operation and Development countries. International Review of Administrative Sciences, 82(4), pp. 763-783.

BRUSCA, Isabel; CAPERCHIONE, Eugenio; COHEN, Sandra and MANES-ROSSI, Francesca (eds.) (2015) - Public Sector Accounting and Auditing in Europe - the Challenge of Harmonization, Basingstoke: Palgrave Macmillan, ISBN: 978-1-137-46133-9.

\section{Discussion topics}

- Reasons for consolidated financial reporting in the public sector

- Information needs fulfilled by public sector CFS

- Consolidation methods: Which suits best in the public sector? 